\title{
Rizaitdin Fakhretdin's spiritual experience in the development of the ideas of enlightening the peoples of the Volga and the Urals at the turn of the 19th-20th centuries: a historical and philosophical analysis
}

\author{
Rushalina Lukyanova ${ }^{1, *}$ \\ ${ }^{1}$ M. Akmullah Bashkir State Pedagogical University, 450008, 3a Oktyabr'skoy revolyutsii str., Ufa, \\ Russia
}

\begin{abstract}
This article attempts to analyze the educational views of an outstanding scholar-theologian of 19th-20th century, Rizaitdin Fakhretdin, whose fate and activities reflected the vicissitudes of the complex historical era of the changes in pre-revolutionary Russia and the hard years of the establishment of Soviet power in the regions of the Volga and the Urals. The spiritual dominant, as a factor of Enlightenment, forms the basis of the evolutionary development of the society. In the conditions of the development of modern Russia and the urgent need to develop the principles of peaceful coexistence of peoples and concessions, the philosophical study of the national and cultural heritage, spiritual experience, the values and traditions of generations, the place and role of ethnonational communities, the destinies of its ideological enlighteners in the spiritual life of modern Russia is of the highest importance. The article also focuses on the development of the spirituality of human being and the degree of enlightenment of the society, which are the foundation of the unity, stability, strength, and greatness of society and the state.

The choice of the topic is dictated by both theoretical interest and practical needs. The contemporaru image of multinational Russia requires a serious historical and philosophical analysis of its social development. The heterogeneous immune nature of the Russian civilization facilitates the assimilation of spiritual and practical experience in the conditions of the coexistence of different peoples. The use of unique socio-historical knowledge stimulates the widening of the capacity of every social, confessional, national community to be involved in the strengthening of Russian unity.
\end{abstract}

* Corresponding author: rusha-09@ mail.ru 


\section{Introduction}

In the situation of transforming the main spheres of life, it is important to consider the problems of preserving and reproducing the educational potential in the general context of social, cultural, and political changes.

The appeal to the world outlook of the enlightenment movement is justified by the realization that society is not able to develop steadily in the conditions of destructive manifestations in the system of education and upbringing.

\section{Problem Statement}

Rizaitdin Fakhretdin and his role in the development of ideas of enlightening the peoples of the Volga and the Urals at the turn of the 19th-20th centuries are the main focus of the paper.

The legacy of Rizaitdin Fakhretdin in the history of enlightenment in the Volga and the Urals at the turn of the 19th-20th centuries is studied with the help of a historical and philosophical analysis.

\section{Research Questions}

The pre-revolutionary period of the life of a theologian-theologian includes the $60-80 \mathrm{~s}$ of the 19 th century up to the 20 s of the 20 th century). The research focuses on the following stages in his development:

- The early path of Rizaitdin Fakhretdin (childhood, learning);

- The beginning of his professional and pedagogical activity (family, training as a mentor);

- Kazy in Spiritual Management;

- The Publishing House of the newspaper "Vakyt" (1906-1908);

- The Editorial Board of the magazine "Shura" in the period from 1908-1918.

The post-revolutionary period of the enlightener's activity (30-40s of the 20th century) includes:

- The social and political activities of Rizaitdin Fakhretdin in Moscow in 1918.

- Becoming a mufti of the Central Spiritual Board of Muslims of Inner Russia and Siberia (1922).

- Scientific and publishing activities of Rizaitdin Fakhretdin.

\section{Purpose of the Study}

The aim of the research is the archectonics of the historical and philosophical worldview as a totality of such ethno-cultural invariants that can be regarded as the forces that create and form the spiritual experience of the heritage of the enlightener, scientist, and theologian Rizaitdin Fakhretdin.

The paper analyzes the main conceptual approaches of the enlightenment movement in public life and culture of the peoples of the Urals and the Volga region in the second half of the 19 th and early 20 th centuries.

Also, the paper aims to justify the concept of "Enlightenment" as an aggregate of spiritual values, where true spirituality rests on goodwill and reason, forming the ideals of nobility, generosity, justice, truth, and beauty. 


\section{Research Methods}

As a methodological basis of the study is the understanding of the ideas of Enlightenment, acting as a transforming factor, creating the forces of the educational spirit of generations in the person of Rizaitdin Fakhretdin. With a historical and philosophical approach, a comparative and casual analysis is connected, according to which education cannot be comprehended only from oneself, for its investigation it is necessary to cause and effect relationships in a broad historical context that covers the real life activity of people, the patterns of development of spiritual and social life.

\section{Findings}

It is substantiated that the meaning-forming forms of spiritual existence determine the sphere of philosophical analysis: they order and connect history with the fate of the enlightener into one single whole, including past, present, and future.

Personally, we believe that the name of the famous scientist and theologian Rizaitdin Fakhretdinov will remain not only in the history of Russia, but also in the world educational thought of the 19th-20th centuries.

For a number of objective and subjective reasons, special literature on the life and activities of Rizaitdin Fakhretdin is not numerous. The first notes about him and his works appeared even before 1917. The words of the great Tatar poet Gabdulla Tukai deserve attention, who highly appreciated the first literary works of R. Fakhretdin in a letter to Ahmed Urmanchiev. It should be also noted that the author of these works was critical enough about himself and his work, saying that "he understands little in the creation of art works" [3].

Rizaitdin Fakhretdinov, who is also Rizaetdin (Riza), Rizaitdin bin Fakhretdin, was born on 22.12.1858 (4.01.1859) in the village of Kichuchatovo (Yuldash) of the Bugulma district of the former Samara province (the Almetyevsky district of Tatarstan) in the family of the imam-mudaris Fakhretdin Bin Sayfutdin. The history of his family dates back to the times of the Bulgarian kingdom:

1. Tansar;

2. Karmysh Al-Bulgaribine Tansar;

3. Bachhand (Buck shunda) Binet Karmysh;

4. Kaibullah (Habibullah) Binet Bakshand;

5. Zhankilde Binet Kaibula;

6. Tumkai (Tuy-Muhammet) Binet Zhankilde;

7. Ishkaym (Ishmuhammet) Binet Tumkai;

8. Yuldash Binet Ishkai;

9. Bikmuhammet Binet Yuldash;

10. Subhankul Binet Bikmuhammet;

11. Saifetdin Binet Subkhan-kul (1778-1861);

12. Fahretdin Binet Sayfetdin (1819-1891);

13. Rizaitdin Binet Fahretdin (1859-1936).

Riza was born in the Imam's family. Serious training of Rizaitdin from the Sufi sheikh Zakir-Ishan Kamalov began in 1867 in madrassas at the 1st Chistopol mosque. In his student years, he collected a manuscript library from the works of thinkers of the Ancient East. Possessing Arabic, Persian, and Turkish languages, Rizaitdin started teaching activities (80th of the 19th century) among the younger students of the madrasah. For their studies, Rizaitdin Fakhretdin composed textbooks of mathematics and the Tatar language being published in 1886-1887. In the same year (1887), in Kazan was published "Book of Morphology" ("Kitabetbeetesrif'), the work of Rizaitdin Fakhretdinov, introducing the 
reader to the grammar of the Arabic language. Later, on a fee from the sale of one of his books, Rizaitdin managed to build and open a new school. In the years of his education, Rizaitdin Fakhretdin studied hard and diligently. There are 10 volumes of manuscripts copied to him in different years [4].

The chronicle testifies that Rizaitdin Fakhretdin was married since 1885 and had a large family [5]:

1. A wife - Nurjamal (Nurizigan) Abdulnasyrovna;

2. A son - Gabdrakhman (1887-1936);

3. A son - Gabdulahad (1889-1938);

4. A son - Gabdrasid (1892-1953);

5. A daughter - Zainab (1893-1985);

6. A son - Sahid (1900-1944);

7. A daughter - Asma (1906-1993).

A large family required a lot of strength and care, but despite the difficulties, Rizaitdin Fakhretdin could find time for conducting research. "In 1887, he successfully stands the test for the position of Imam. The glory of the young talented mentor from Kichuchata scattered all over the edge. In July 1889, the community of Ilbak village of Bugulma district invited R. Fakhretdinov to the position of alocal imam and mudaris" [6]. In the mosque of this village, Rizaitdin served until February 1891.

In his writings, Rizaitdin Fakhretdin pays special attention to the issues of morality. Extremely popular among readers were the books about education. They were repeatedly reprinted in 1898-1916 in Kazan, Ufa, anf Orenburg in the series of the traditional genre "Nasihat" ("manual"). Separate issues contained treatment for children. There were volumes to adult members of the family: "Raised father," "Raised mother," "Raised woman; the problems in the family and the school are addressed in the "Child Upbringing," "Novometodnaya School," "Persuasion," and others. Riza writes, "The work of mothers is the hardest and painstaking. If the gardeners are praised, they grew apple, orange, lemon gardens, then mothers who raised and raised good children are praised" [7].

Rizaitdin Fakhretdinov is a major religious figure and publicist. He wrote the story "Salima, or Chastity" (1889), “Asma, or Misdemeanor and Punishment" (1903), in which he advocated the initiation of his people to the achievements of European culture, raises the problem of women's emancipation. In the work "Culture of Discipleship," Riza speaks of knowledge as a blessed adornment of each person and the best of merit: "Knowledge is the cause of getting rid of any difficulties. Knowledge is a treasure that never ends. Knowledge is a light that in this world saves from blindness, and in that world from torment. Knowledge is a friend in isolation, sharing secrets in a foreign land, decorating in front of friends, sharp weapons against enemies... Knowledge is such a blessing that when a person does not need other goods" [8].

In 1891, Rizaitdin Fakhretdin, being known for his work, was invited to the post of Kazy in the Spiritual Directorate. Researcher R. Mardanshin writes that Fakhretdin, when he saw a lot of manuscripts lying "dead weight: in the archive of the DUM, caught fire with his own research. Recalling this incident, he said laughing: "If someone watches me from the side, he would say: what kind of riches are the cadias looking for in the archives of Riza... However, for me to know the true dates of the birth or death of three or four scientists is more expensive than bucket of gold" [9].

In 1906, R. Fakhretdinov moved to Orenburg and worked in the publishing house of the newspaper "Vakyt" (1906-1908). In the period from 1908-1918, Rizaitdin headed the editorial board of the magazine "Shura." Almost every issue under the heading "Remarkable people and great events" published biographical information about eminent figures of culture and science, accounting to 170/179 names, including Gazali, Ibn Rushd, Descartes, Mechnikov, and others. Many of these essays are published later by separate 
books. The materials of the journal published the programs of subjects of the new-method educational institutions, curricula. The main historical work of Fakhretdinov is the multivolume historical and biographical work "Asar"' ("Works:). The first two volumes published in Orenburg (1900-1908) contain about 1 thousand biographies of Muslim culture figures. The manuscript of the last volumes is considered missing. It was seized by the police during a search in the house of Fakhretdinov in 1911.

The works of Rizaitdin Fakhretdin contain religious and educational ideas that exerted a great influence on the subsequent changes in the social life of the Turkic peoples. "Nations worthy of living in the world," writes Rizaitdin, "and must have independent, sovereign thinking and worldview, progress according to the changes and progress of the era ... The peoples came to the world not to stand in the path of life, and then, to go on relentlessly forward and strive to skyrocket" [2].

Among the forbidden publications of Fakhretdinov's book is "Dini ve ijtimagyhmselaler" ("Religious and Social Problems," Orenburg, 1914) seized by the authorities by denunciation. These facts are another evidence of the depth of Fakhretdinov's knowledge, his feelings and a detailed analysis of the cultural and political changes taking place in Russia and on its outskirts.

The main work of Fakhretdinov in the field of theology is "Religious and Social Issues." It outlines the main provisions of Islam. Another significant theological work is "A Commentary on the Sayings of Muhammad." The work that reveals the ethical norms of "Jau-Migulkelimshareh" ("Comments on the Prophet's Sayings," Orenburg, 1916) is a work by Fakhretdinov, which was the result of the pedagogical research of the thinker. The book was studied and rewritten (in Cyrillic) in 1980-1986. The book, with the translation of Arabic words, was getting prepared for publication by R. Utybaev-Karim since 1986.

Literary and journalistic activities of Fakhretdinov contributed to the formation of a wide range of Muslim readers and their orientation to the problems of traditional and modern culture. In December 1917, Rizaitdin participated in the work of the III All-Bashkir Constituent Assembly (Congress).

From the scientific work of Rizaitdin Fakhretdinov, a new stage in the development of public thought in Bashkortostan begins. Fahretdinov returned from Orenburg to Ufa in 1918, after the closure of the journal "Shura." In the same year of 1918, submitting to the decision of the All-Russian Congress (Moscow), Rizaitdin again took the position of Qadiy in Ufa. And since 1922, Fakhretdinov was elected a mufti of the Central Spiritual Board of Muslims of Inner Russia and Siberia. The Tatar scientist A. Khairullin wrote that Rizaitdin Fakhretdin collaborated with the famous politician and religious reformer D. Afgani, academician Samoilovich, as well as with scientists Bartold and Krachkovsky. Despite his busy years and advanced age, Fakhretdinov was seriously concerned with the problem of saving the archive of the Spiritual Assembly of Muslims in Ufa, having begun work on systematization and studying of its historical documents.

With Fakhretdinov's election as Mufti and head of the Spiritual Directorate, he intercedes with the People's Commissariat for Nationalities on the publication of a religious journal. In 1924, Rizaitdin Fakhretdin finally succeeds in obtaining a permission to publish it. The pages of the magazine publish the articles of Fakhretdinov, Tarjimanov, Kazy Jahangir Abyzgildin, Mukhlis Bubinsky, theological works, surahs of the Koran, and information materials.

In 1927, the TsDUM united about 14,825 parishes. But by May 1930, more than 10,000 mosques were closed, $90-97 \%$ of the mullahs and muezzins were deprived of the opportunity to perform their duties. Fakhretdinov could not help but protest against such decisions. Despite the arrests, the closure of mosques, and the destruction of religious literature, Rizaitdin Fakhretdin managed to save part of the documents in the archive. 
A. Khairullin writes that the last years of his life for R. Fahretdin were in difficult material conditions. He was approached several times with a proposal from the Vienna Academy of Sciences to sell a personal archive, but each time Rizaitdin Fakhretdin refused. Later, most of the surviving manuscripts, at the request of the famous orientalist, Academician A. N. Samoilovich, Rizaitdin will be transfered to the archive of the Leningrad Branch of Oriental Studies of the USSR Academy of Sciences.

Rizaetdin Fakhretdinov died on April 11, 1936 at the age of 78. Having gone through a difficult life, Rizaitdin Fakhretdin managed to preserve spiritual purity, kind heart, develop a clear mind, and talent of the scientist who knows the Truth. After his death, mass arrests of the leadership of the Spiritual Administration began. A well-known Tatar scholar A. K. Khabutdinov describes such sad events, "Thousands of Muslims, hearing about Fakhretdin's death, gathered secretly at night in his native village to read the "janaz" ("memorial prayer") for the deceased" [2]. Raisaitdin Fakhretdin was buried in a Muslim cemetery in Ufa.

For the decades, the life and work of the Enlightener remained a closed topic. The scientific community turned to his work only in the 1960s. "'Today we are witnessing a situation where the rejection of traditional moral values, the revision of the historical path of the state, the introduction of the consumer cult in the public consciousness form new values in the minds of Russians, consistently replacing the age-old traditions and the historical past" [2].

In today's tough confrontation between the West and the East, caused by another economic and political crisis, the recognition of the paradigm of the multipolar world is obvious. The experience of Russia, representing its national and cultural heritage of peoples, acquires special significance of philosophical research in the prevailing conditions. As of today, the name of Rizaitdin Fakhretdin occupies a worthy place in the list of major Muslim scholars-theologians of the 20th century.

Living openly is quite difficult, it is difficult to learn how to give everything away. But it is precisely this dedication that is the purity, the greatness of Rizaitdin Fakhretdin, who calls the people of the whole world, different views and beliefs, to unite, realize, and overcome the path of chaos and callousness, stepping onto the path of prudence, spiritual renewal, and enlightenment.

\section{Conclusion}

The decomposition of feudal structures and the formation of capitalism with accompanying changes in public life and culture of the peoples of the Urals and the Volga region contributed to the emergence in the second half of the 19th and the beginning of the 20th century. Enlightenment movement, which distinguish two areas: religious and reformatory and democratic. Reforms of education educators correlated with the social and religious movement - Jadidism (Jadidism-new), condemning the views of the reactionary clergy, represented by the current - kadimizm (kadim-old) with his scholastic school.

Characterizing the dissemination of the basic ideas of enlightenment of this period in general, it can be noted that his intellectual potential is determined: (a) firstly, by focusing on the human problem, and in this connection, there is a tendency to absolutize the role of moral and ethical factors in the development of society; (b) secondly, the views of enlighteners are directed towards the ideas of national self-knowledge, and this explains their interest in solving social problems.

The enlightenment expressed people's needs in the sense of his involvement in the foundations of being. The ideas of enlightenment are formed in the space of society, being reflected in the views of the enlighteners of their era. The works of Rizaitdin Fakhretdin 
represent spiritual experience, being an element of the ideological, cultural, and political life of the Russian society at the turn of the 19th and 20th centuries.

\section{References}

1. R. bin Fakhretdin, Culture of apprenticeship: shackerdle edebi (Publishing House of the Imperial University, Kazan, 1899)

2. R. A. Lukyanova, The path of truth by Rizaitdin Fakhretdin (Publishing House of the Belarusian State Pedagogical University, Ufa, 2014)

3. R. bin Fakhretdin, Collection on the old Tater languages: the Raised Mother [Terbilele ana] (Publishing House of the Imperial University, Kazan, 1898)

4. http://www.infoislam.ru/publ/religija/tatarskie_bogoslovy/tatarskie_bogoslovy_riza_f akhretdin_1859_1936/39-1-0-28003

5. R. bin Fakhretdin, Collection on the old Tater languages: the Raised Mother [Terbilele ana] (Publishing House of the Imperial University, Kazan, 1898)

6. R. bin Fakhretdin, Culture of apprenticeship: shakerdlek edebi (Publishing House of the Imperial University, Kazan, 1899)

7. A. K. Khabutdinov, Islam in the Russian Federation: the 150th anniversary of Rizaitdin Fakhretdin (http://pda.islamrf.ru/news/culture/legacy/6881)

8. R. A. Lukyanova, The way of truth by Rizaitdin Fakhretdin: Reader (BSPU Publishing House, Ufa, 2014)

9. F. S. Fyzullin, A. Ya. Zaripov, Ethnos as a subject of public relations (Gilem, Ufa, 2013) 